Research Article

\title{
First Report of Aprostocetus asthenogmus (Hymenoptera: Eulophidae) in South America and Parasitizing Eggs of Triatominae Vectors of Chagas Disease
}

\author{
Claudiney Biral dos Santos, ${ }^{1,2}$ Marcelo Teixeira Tavares, ${ }^{3}$ Gustavo Rocha Leite, ${ }^{1,4}$ \\ Adelson Luiz Ferreira, ${ }^{1,5}$ Leonardo de Souza Rocha, ${ }^{6}$ and Aloísio Falqueto ${ }^{1}$ \\ ${ }^{1}$ Unidade de Medicina Tropical, Universidade Federal do Espírito Santo (UFES), Avenida Marechal Campos 1468, \\ 29043-900 Vitória, ES, Brazil \\ ${ }^{2}$ Núcleo de Entomologia e Malacologia do Espírito Santo, Secretaria de Estado da Saúde do Espírito Santo, Rua Pedro Zangrande 381, \\ 29164-020 Serra, ES, Brazil \\ ${ }^{3}$ Laboratório de Biodiversidade de Insetos, Universidade Federal do Espírito Santo (UFES), Avenida Marechal Campos 1468, \\ 29043-900 Vitória, ES, Brazil \\ ${ }^{4}$ Setor de Parasitologia, Departamento de Patologia, Centro de Ciências da Saúde, Universidade Federal do Espírito Santo (UFES), \\ Avenida Marechal Campos 1468, 29043-900 Vitória, ES, Brazil \\ ${ }^{5}$ Escola Superior de Ciências da Santa Casa de Misericórdia de Vitória (EMESCAM), Avenida Nossa Senhora da Penha 2190, \\ 29045-402 Vitória, ES, Brazil \\ ${ }^{6}$ Centro Universitário do Espírito Santo (UNESC), Rua Fioravante Rossi 2930, 29703-855 Colatina, ES, Brazil
}

Correspondence should be addressed to Gustavo Rocha Leite; gugarl@gmail.com

Received 19 September 2013; Accepted 7 November 2013; Published 19 January 2014

Academic Editor: Dave Chadee

Copyright (C) 2014 Claudiney Biral dos Santos et al. This is an open access article distributed under the Creative Commons Attribution License, which permits unrestricted use, distribution, and reproduction in any medium, provided the original work is properly cited.

\begin{abstract}
We report for the first time the parasitism of eggs of two triatomine Chagas disease vectors, Triatoma infestans and T. vitticeps, by the microhymenopterous parasitoid Aprostocetus asthenogmus. We also describe the first identification of this parasitoid in South America. A. asthenogmus were captured near unparasitized triatomine colonies in the municipality of Vitória, state of Espírito Santo, Brazil, and placed into pots with recently laid triatomine eggs. After 24 days, we observed wasps emerging from T. infestans and T. vitticeps eggs. Several characteristics of this parasitoid species suggest that it could be a potential biological control agent of triatomine species.
\end{abstract}

\section{Introduction}

Triatominae (Hemiptera, Reduviidae) is a subfamily of hematophagous insects known as "kissing bugs" whose members are principally distributed throughout the Neotropical region [1-3]. Certain triatomine species are responsible for the transmission of Trypanosoma cruzi Chagas, 1909 (Kinetoplastida, Trypanosomatidae) - the etiological agent of Chagas disease, which is one of the most dreaded parasitic diseases of Latin America [4].

Attempts to control T. cruzi transmission began soon after Carlos Chagas' work in the 1900s. The advent of synthetic insecticides in the 1940s was the first major breakthrough in identifying effective techniques for kissing bug control; the introduction of pyrethroids, a more cost-effective synthetic type of insecticide, was another important advance that occurred in the 1980s [5]. Despite these efforts, high levels of vector-borne transmission still occur in many areas, and several endemic countries had to develop large-scale surveillance and intervention programs [6].

Since the Chagas disease discovery, the biological control of its vectors has been considered [7-10]. However, its application to effective triatomine control in the field is still incipient; little success has been achieved by the 

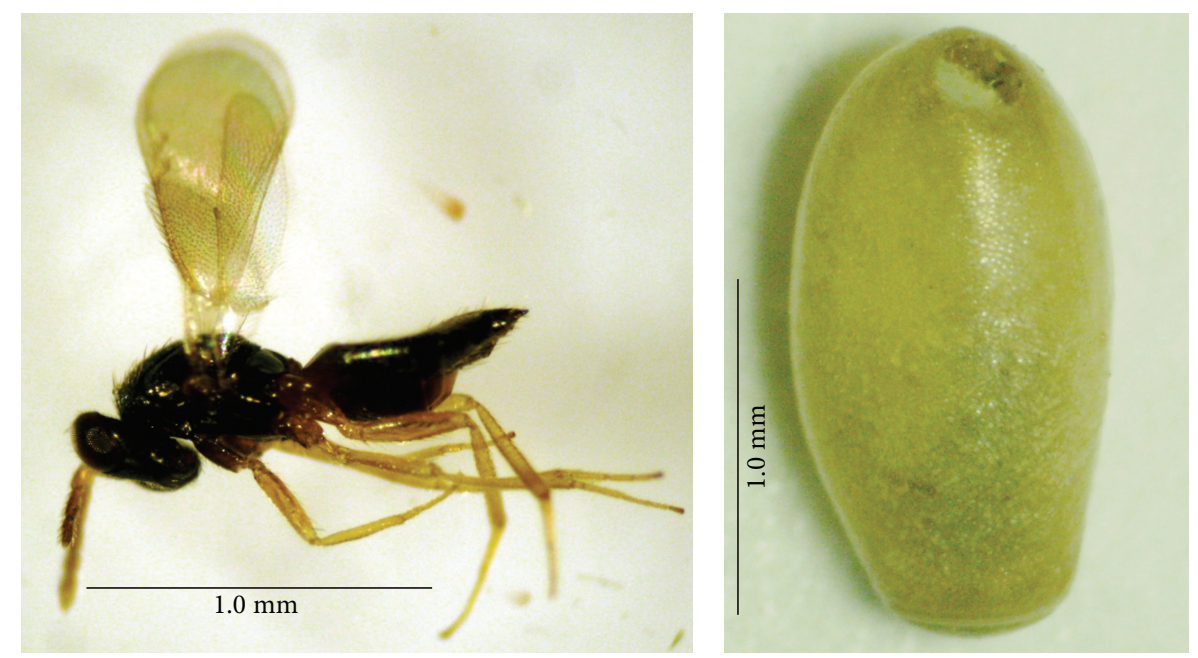

FIgURe 1: Parasitoid wasp Aprostocetus asthenogmus (Waterston, 1915) and Triatoma vitticeps (Stål, 1859) egg.

use of parasitoid wasps [10], although recent studies with entomopathogenic fungi are promising [11]. Several species clustered in different taxonomic groups might function as triatomine pathogens, predators, or parasitoids $[12,13]$. For example, the best-known kissing bug parasitoid Telenomus fariai Lima, 1927 (Hymenoptera, Scelionidae), is able to parasitize the eggs of species in three triatomine genera, Panstrongylus, Rhodnius, and Triatoma $[12,14,15]$. Parasitoid wasps are distributed throughout the world in a variety of environments [16] and usually parasitize the eggs of a wide range of insects, many Triatominae species among them [12]. They are considered to have biological, ecological, and economic importance, and some species are employed as pest biological control agents $[17,18]$.

In this communication, we report for the first time the experimental parasitism of eggs of the triatomine species Triatoma infestans (Klug, 1834) and Triatoma vitticeps (Stål, 1859) by Aprostocetus asthenogmus (Waterston, 1915) (Hymenoptera, Eulophidae). This species is an endophagous egg parasite that has only been reported to parasitize the ootheca of the cockroaches Periplaneta americana (Linnaeus, 1758), Periplaneta australasiae (Fabricius, 1775), and Periplaneta brunnea Burmeister, 1838 (Blattodea, Blattidae) [19, 20]. We also report the first record of $A$. asthenogmus in South America, which has previously been recorded in the Caribbean, India, North Africa, the Palearctic, China, Seychelles, and Sri Lanka [19, 21-24]. We also discuss its potential as a biological control agent of domiciliary triatomine species.

\section{Materials and Methods}

In January 2005, we observed $A$. asthenogmus adult wasps flying near T. infestans and T. vitticeps colonies established in 2004 at the Unidade de Medicina Tropical of Universidade Federal do Espírito Santo, municipality of Vitória, state of Espírito Santo, Brazil $\left(20^{\circ} 17^{\prime} 53^{\prime \prime} \mathrm{S}, 40^{\circ} 18^{\prime} 58^{\prime \prime} \mathrm{W}\right)$. However, the triatomines and their eggs were maintained in meshcovered pots, preventing any spontaneous wasp-triatomine egg contact. We carried out an investigation to determine if A. asthenogmus was able to parasitize triatomine eggs. The adult wasps were captured using a Castro suction device and placed into two pots with recently laid eggs: 11 wasps with 51 eggs of T. infestans and 10 wasps with 79 eggs of T. vitticeps. The pots were maintained at an environmental temperature $\left(\sim 28^{\circ} \mathrm{C}\right)$ and observed daily for wasp emergence.

\section{Results and Discussion}

After 24 days, we observed wasps emerging from triatomine eggs. Among T. infestans eggs, 29 (56.8\%) became parasitized and produced 29 adult wasps, whereas 36 (45.5\%) T. vitticeps eggs were parasitized and produced 36 adult wasps (Figure 1).

Microhymenoptera of the Aphelinidae, Eupelmidae, Encyrtidae, Pteromalidae, and Scelionidae families were previously reported to parasitize Triatominae eggs naturally and experimentally $[7,12]$. However, this is the first report that Eulophidae are able to parasitize triatomine eggs $[19,20]$.

In cockroaches, $A$. asthenogmus exhibits gregarious habits with a mean of 69.5 parasitoids emerging per ootheca (approximately $9 \times 6 \mathrm{~mm}$ ), which can contain up to $16 \mathrm{eggs}$, and a mean development time of 43 days $[19,25,26]$. In the two species of triatomine we used, however, $A$. asthenogmus showed a solitary habit, with only one adult emerging from each egg and a shorter development time. These differences could be partially explained by the size variation between triatomine eggs and cockroach oothecas and less resource competition.

T. vitticeps has been reported to be parasitized only by T. fariai, but $T$. infestans is reportedly parasitized by other microhymenopteran species in addition to T. fariai $[12,14,15]$. T. vitticeps is a wild and endemic species of the Atlantic Forest that is responsible for sporadic cases of human Chagas disease in that region [27-30], and T. infestans is considered the most important domiciliated T. cruzi vector that was previously widely distributed in South America [31, 32]. 
Although it could be considered that the particular laboratory conditions (e.g., scarcity of natural hosts and the confinement imposed) could have stimulated A. asthenogmus to use nonnatural hosts, our confirmation of parasitism of triatomine eggs suggests the possibility of this parasitoid acting as a natural enemy of these two species of T. cruzi vectors. Several characteristics of this species suggest that it could be a potential biological control agent of triatomine eggs: A. asthenogmus was apparently attracted by the triatomine colony, it shows a wide geographical distribution, it is a natural parasitoid of several worldwide cockroach pest species, and it requires no preovipositional period (at least in cockroaches) and accepts 1- to 30-day-old oothecae [25]. It is also promising that the adult wasp developmental time in triatomine eggs was shorter than in cockroach oothecae; moreover, only one adult wasp emerged per triatomine egg, allowing a unique female to parasitize a potentially greater number of triatomine eggs.

\section{Conclusions}

A. asthenogmus, first recorded in South America, can parasitize eggs of triatomines, suggesting that it could be a potential biological control agent of these Chagas disease vectors. On the basis of these findings, we suggest that new studies should be carried out to evaluate the host preference plasticity of $A$. asthenogmus in new environments and its potential as a biological control agent of domiciliary and peridomiciliary triatomine species. Experiments evaluating sex ratios, parasitism capacity, dispersal ability, and possible female wasp competition for egg parasitization (including possible egg-marking behavior) should be included in future work.

\section{Conflict of Interests}

The authors declare that there is no conflict of interests regarding the publication of this paper.

\section{Acknowledgments}

The authors wish to acknowledge Danielle de Oliveira Moreira from Universidade Federal do Espírito Santo and Jorge Rabinovich from Universidad Nacional de La Plata for carefully reviewing this paper.

\section{References}

[1] M. S. Rodriguero and D. E. Gorla, "Latitudinal gradient in species richness of the New World Triatominae (Reduviidae)," Global Ecology and Biogeography, vol. 13, no. 1, pp. 75-84, 2004.

[2] C. Galvão, R. Carcavallo, D. S. Rocha, and J. Jurberg, "A checklist of the current valid species of the subfamily Triatominae Jeannel, 1909 (Hemiptera, Reduviidae) and their geographical distribution, with nomenclatural and taxonomic notes," Zootaxa, vol. 202, pp. 1-36, 2003.

[3] J. A. F. Diniz-Filho, S. Ceccarelli, W. Hasperué, and J. Rabinovich, "Geographical patterns of Triatominae (Heteroptera:
Reduviidae) richness and distribution in the Western Hemisphere," Insect Conservation and Diversity, 2013.

[4] WHO, Control of Chagas Disease: Second Report of the WHO Expert Committee, World Health Organization, Geneva, 2002.

[5] J. C. P. Dias, A. C. Silveira, and C. J. Schofield, "The impact of Chagas disease control in Latin America-a review," Memórias do Instituto Oswaldo Cruz, vol. 97, no. 5, pp. 603-612, 2002.

[6] J. C. P. Dias and C. J. Schofield, "The evolution of Chagas disease (American trypanosomiasis) control after 90 years since Carlos Chagas discovery," Memórias do Instituto Oswaldo Cruz, vol. 94, no. 1, pp. 103-121, 1999.

[7] R. E. Ryckman and C. M. Blankenship, "The parasites, predators and symbionts of the Triatominae (Hemiptera: Reduviidae: Triatominae)," Bulletin of the Society for Vector Ecology, vol. 9, no. 2, p. 84, 1984.

[8] J. Rabinovich, "Simulación en una computadora digital de la regulación poblacional de triatominos vectores de la Enfermedad de Chagas por el parásito Telenomus fariai (Hymenoptera: Scelionidae) y de las estrategias para control integrado," Revista Peruana de Entomología, vol. 14, no. 1, pp. $117-126,1971$.

[9] A. M. C. Lima, "Sur le Telenomus fariai nouveau parasite endophage des oeufs de Triatoma megista Burm," Comptes Rendus des Séances et Mémoires de la Société de Biologie, vol. 97, no. 31, p. 1350, 1927.

[10] J. E. Rabinovich, J. A. Leal, and D. Feliciangeli de Piñeiro, Investigación de campo sobre el uso de microhimenópteros para el control biológico de los vectores del Trypanosoma cruzi, Informe Técnico CONICIT no. S1-697, Caracas, Venezuela, 1980.

[11] N. Pedrini, S. J. Mijailovsky, J. R. Girotti et al., "Control of pyrethroid-resistant chagas disease vectors with entomopathogenic fungi," PLoS Neglected Tropical Diseases, vol. 3, no. 5, article e434, 2009.

[12] M. C. Coscarón, M. S. Loiácono, and L. De Santis, "Predators and parasitoids," in Atlas dos vetores da doença de Chagas nas Américas, R. U. Carcavallo, I. Galíndez-Girón, J. Jurberg, and H. Lent, Eds., Editora Fiocruz, Rio de Janeiro, Brazil, 1999.

[13] C. Luz, I. G. Silva, B. P. Magalhães, C. M. T. Cordeiro, and M. S. Tigano, "Control of Triatoma infestans (Klug) (Reduviidae: Triatominae) with Beauveria bassiana (Bals.) Vuill.: preliminary assays on formulation and application in the field," Anais da Sociedade Entomológica do Brasil, vol. 28, no. 1, pp. 101-110, 1999.

[14] J. Pellegrino, "Parasitismo experimental de ovos de várias espécies de Triatoma pelo microhimenóptera Telenomus fariai Lima, 1927," Memórias do Instituto Oswaldo Cruz, vol. 48, pp. 675-686, 1950.

[15] A. J. Fernandes, J. C. da Silva, and L. Diotaiuti, "Parasitismo natural de ovos de triatomineos por Telenomus fariai Lima, 1927 no laboratório," Revista da Sociedade Brasileira de Medicina Tropical, vol. 23, no. 3, pp. 149-151, 1990.

[16] J. LaSalle and I. D. Gauld, "Parasitic Hymenoptera and the biodiversity crisis," Redia, vol. 74, no. 3, pp. 315-334, 1991.

[17] H. C. J. Godfray, Parasitoids: Behavioral and Evolutionary Ecology, University Press, Princeton, NJ, USA, 1994.

[18] H.-S. Tee, A. R. Saad, and C.-Y. Lee, "Evaluation of Aprostocetus hagenowii (Hymenoptera: Eulophidae) for the control of American cockroaches (Dictyoptera: Blattidae) in sewers and crevices around buildings," Journal of Economic Entomology, vol. 104, no. 6, pp. 2031-2038, 2011.

[19] A. U. Narasimham, "Comparative studies on Tetrastichus hagenowii (Ratzeburg) and T. asthenogmus (Waterton), two 
primary parasites of cockroach oothecae, and on their hyperparasite Tetrastichus sp. (T. miser (Nees) group) (Hymenoptera: Eulophidae)," Bulletin of Entomology Research, vol. 74, no. 2, pp. 175-189, 1984.

[20] B. E. Hagenbuch, R. S. Patterson, and P. G. Koehler, "Biological control of the American cockroach (Orthoptera: Blattidae) with inundative releases of Tetrastichus hagenowii (Hymenoptera: Eulophidae)," Journal of Economic Entomology, vol. 82, no. 1, pp. 90-94, 1989.

[21] J. LaSalle, "North American genera of Tetrastichinae (Hymenoptera: Eulophidae)," Journal of Natural History, vol. 28, no. 1, pp. 109-236, 1994.

[22] L. Masi, "Chalcididae of the Seychelles islands," Novitates Zoologicae, vol. 24, pp. 121-330, 1917.

[23] J. Waterston, "New species of Chalcidoidea from Ceylon," Bulletin of Entomological Research, vol. 5, no. 4, pp. 325-342, 1915.

[24] L. Weng, L. He, and X. Chen, "First description of Aprostocetus asthenogmus (Waterston) from China (Hymenoptera: Eulophidae)," Kunchong Tiandi, vol. 29, no. 2, pp. 88-91, 2007.

[25] L. M. Lebeck, "A review of the hymenopterous natural enemies of cockroaches with emphasis on biological control," Entomophaga, vol. 36, no. 3, pp. 335-352, 1991.

[26] E. E. S. Vianna, M. E. A. Berne, A. M. Chernaki, P. Silveira Jr., and P. B. Ribeiro, "Performance reprodutiva de Periplaneta americana Linneu, 1758 (Blattodea: Blattidae)," Arquivos do Instituto Biológico, vol. 67, no. 1, pp. 99-107, 2000.

[27] C. B. Dos Santos, A. L. Ferreira, G. R. Leite, G. E. M. Ferreira, A. A. F. Rodrigues, and A. Falqueto, "Peridomiciliary colonies of Triatoma vitticeps (Stal, 1859) (Hemiptera, Reduviidae, Triatominae) infected with Trypanosoma cruzi in rural areas of the state of Espírito Santo, Brazil," Memórias do Instituto Oswaldo Cruz, vol. 100, no. 5, pp. 471-473, 2005.

[28] C. B. Dos Santos, G. R. Leite, G. E. Melim Ferreira, and A. L. Ferreira, "Infecção natural de Triatoma vitticeps (Stal, 1859) por flagelados morfologicamente semelhantes a Trypanosoma cruzi (Chagas, 1909) no Estado do Espírito Santo, Brasil," Revista da Sociedade Brasileira de Medicina Tropical, vol. 39, no. 1, pp. 8991, 2006.

[29] C. B. Dos Santos, G. R. Leite, P. A. Sessa, and A. Falqueto, "Dynamics of feeding and defecation in Triatoma vitticeps (Stal, 1859) (Hemiptera, Reduviidae, Triatominae) and its potential in the transmission of Trypanosoma cruzi," Memórias do Instituto Oswaldo Cruz, vol. 101, no. 5, pp. 543-546, 2006.

[30] G. R. Leite, C. B. dos Santos, and A. Falqueto, "Influence of the landscape on dispersal of sylvatic triatomines to anthropic habitats in the Atlantic Forest," Journal of Biogeography, vol. 38, no. 4, pp. 651-663, 2011.

[31] M. D. Bargues, D. R. Klisiowicz, F. Panzera et al., "Origin and phylogeography of the Chagas disease main vector Triatoma infestans based on nuclear rDNA sequences and genome size," Infection, Genetics and Evolution, vol. 6, no. 1, pp. 46-62, 2006.

[32] I. D. L. M. Ferreira and T. P. T. E. Silva, "Eliminação da transmissão da doença de Chagas pelo Triatoma infestans no Brasil: um fato histórico," Revista da Sociedade Brasileira de Medicina Tropical, vol. 39, no. 5, pp. 507-509, 2006. 

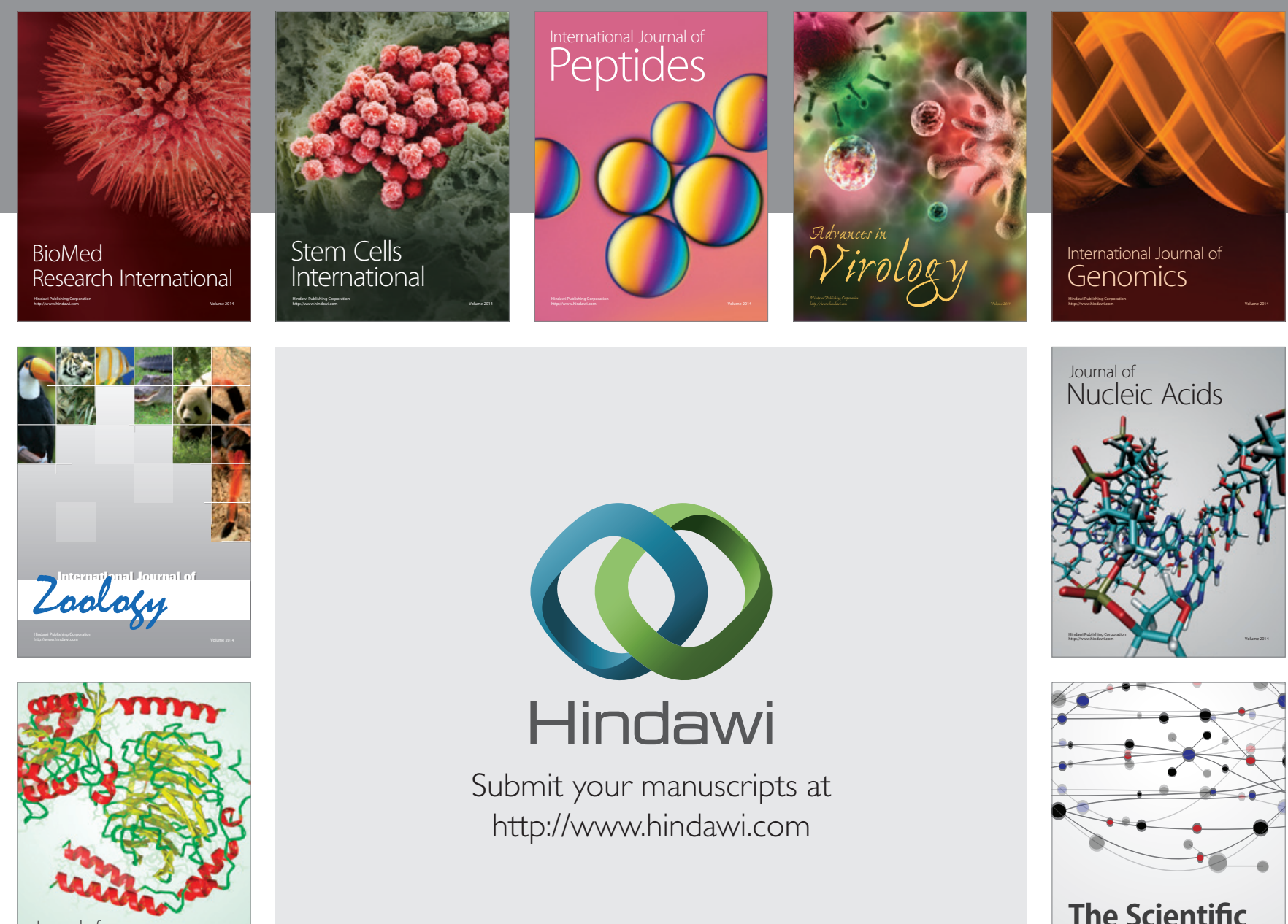

Submit your manuscripts at

http://www.hindawi.com

Journal of
Signal Transduction
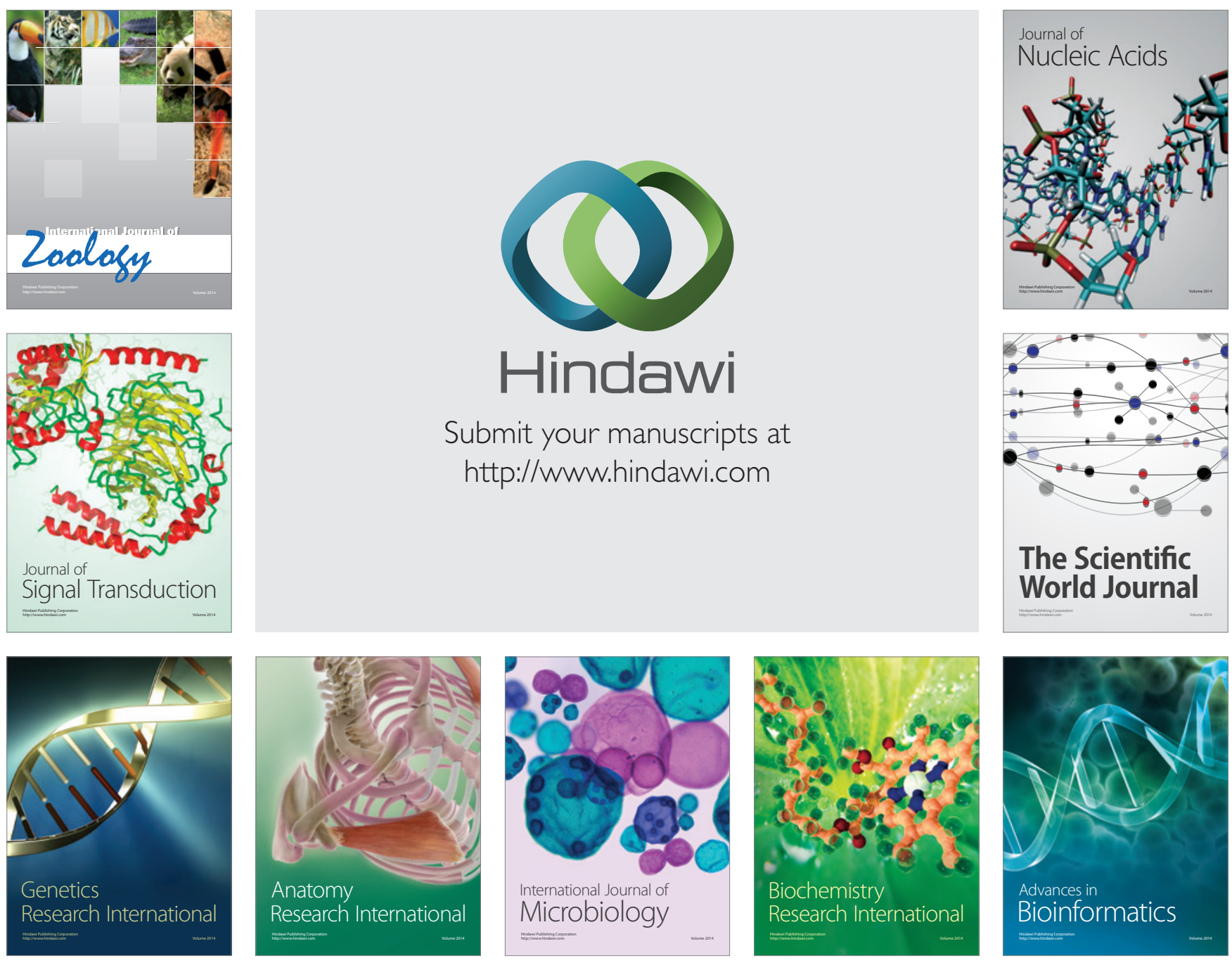

The Scientific World Journal
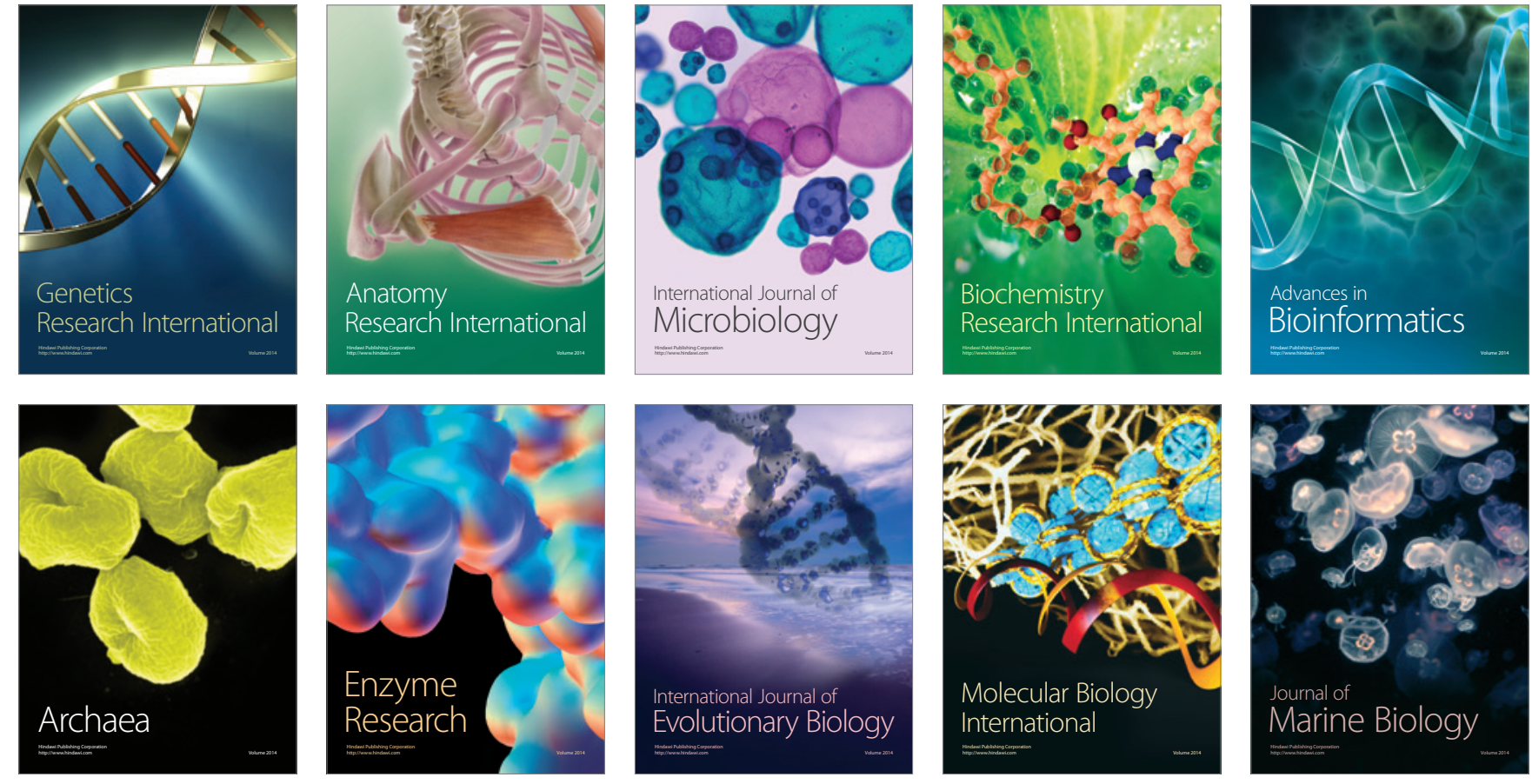